\title{
The Impacts of English National Examination in Indonesia
}

\author{
Taufiq Effendi and Ichwan Suyudi \\ Department of English Literature, Gunadarma University, Depok, Indonesia \\ t_effendi@staff.gunadarma.ac.id or taufiq.effendi@gmail.com, ichwan@staff.gunadarma.ac.id
}

\begin{abstract}
This paper investigates the impacts of the English national examination in Indonesia through a range of research literature. It started off with a brief history of the examination in the country. The study found out that the English national examination as well as the national examination of other subjects generally creates tremendous educational and social impacts. The examination makes students, teachers, principals, parents and society to think that testing skills are vital to let students pass the exam. This resulted in the proliferation of extra classes of testing skills held by schools and tutoring institutions. All this is a result of the negative washback of the national examination.
\end{abstract}

Keywords: negative washback, English national examination, testing skills,

\section{INTRODUCTION}

For many years, English language has been an important subject in Indonesian education. Wealthy Indonesian students in Dutch schools had learned English long before the Indonesian independence (Huda, 1999; Sjamsudin et al., 1993). After the independence, English began to be taught in Indonesian schools (Dardjowidjojo, 2000). English was introduced in primary school as a local content subject in 1994 (Dardjowidjojo, 2000; Yulia, 2014). In 2003, English became a compulsory elementary school subject (Yulia, 2014). However, in 2013, the government instructed that English became an optional extracurricular subject to allow young learners develop their mastery of Bahasa Indonesia.

Since the 1950s, Indonesia has been employing a nationwide standardised English school examination. English national examination has for long been in a multiple-choice format despite the fact that Indonesia has been influenced by different English teaching theories (Dardjowidjojo, 2000). This format is argued to be a powerful tool for evaluating the success of students' learning (Education \& Culture Department, 1996, p. 221). Similarly, Herman and Golan (1993) argue, having investigated more than 300 school teachers in nine different states in the United States, that a large-scale standardised school examination could be utilised as a productive means of improving and controlling the quality of the schooling in a country due to its ability to guide classroom practices. In contrast, in a foreign language learning context, scholars have criticised that multiple-choice tests could unlikely provide credible evidences of test takers' actual language ability in real life situations (Bachman \& Palmer, 1996; Fulcher \& Davidson, 2007; Hughes, 2012; Weir, 2005). This highlights a mismatch between the nature of a multiple-choice English national examination with the actual need for assessing students' real ability of the target language. Mainly for this reason, this paper seeks to investigate what impacts the English national examination has on the school community and society.

\section{A BRIEF REVIEW OF ENGLISH NATIONAL EXAMINATION}

The English national examination has gone through a significant development. Ever since English was included in the curriculum of the post-independence Indonesia, the Indonesian government has used a nationwide multiplechoice written test to assess the results of the elementary and high school students' final year achievements (Huda, 1999; Yulia, 2014). The test result was used to pass or fail students (Education \& Culture Department, 1996). Yet, in 2011, due to the widespread protests by teachers and parents, the government decided that the national examination results, including the English test, were no longer used as the single determiner to pass or fail students; the results held 60 per cent and the rest was based on the school examination (Mukminin et al., 2013; Yulia, 2014, p. 43). Finally, early in 2015, the new minister of culture and elementary and secondary education declared that the national examination results will not determine graduation.

\section{IMPACT AND ITS IMPORTANCE}

The above review highlights that impact is an essential aspect to take into account. Impact is argued to be an essential consideration prior to developing and administering a test. This highlights that, as what Messick (1989) cited in Weir (2005, p. 37) argues, it is essential for test developers to consider the fact that the usefulness and satisfactoriness of the interpretation and use of the test results significantly rely on the consequences of the test results. Many people in many places greatly depend on test results which either fail or pass them e.g. for university admission, job employment etc. In educational setting, Green (2006), Harlen (2005), and Hughes (2012) reported that testing has potential impacts on teaching and learning. This is why Weir (2005) considers impact as "consequential validity" which significantly contributes to the validity of the interpretation and use of the results of a test. This highlights, "assessments are validated not simply by their outcomes, but also by what happens as a result of those outcomes (Wiliam \& Black, 1996, p. 539).

At this stage, it is important to point out that there is not much research found (or probably done) in the area of impacts of English national examination in Indonesia. More studies have been conducted to investigate the impacts of the 
school national examination in general on students, teachers, parents, school principals and also on the society at large. The studies mostly employed questionnaires and interviews to collect the data but only few looked at how classrooms of different grades operate as affected by the exam. All of the research, however, took place prior to the 2015 policy. The findings, therefore, were the reflection of the impacts of the examination that was used as a decisive determiner for students' school graduation. For data management purposes, in the following section of the paper, based on what Weir (2005, p. 14) outlines, the discussion of the impacts of the English national examination is divided into two main parts-the educational impacts on students' learning, teachers' teaching and schools' policy and social impacts on parents and the society at large.

\section{REVIEW OF THE EDUCATIONAL AND SOCIAL IMPACTS OF THE ENGLISH NATIONAL EXAMINATION IN INDONESIA}

Studies showed that the exam affected students' learning. It made students to study much longer. Mardapi and Kartowajiran (2009) conducting their research in Sleman Yogyakarta reported that the majority of the 400 students from 20 different schools they surveyed had up to fifteen extra hours every week. They spent this additional time for tutoring classes at or outside school. Sukyadi and Mardiani (2011) and Suroyo (2012) reported that students had a great deal of exercises which resemble the items of the exam. Most of the teachers thought that the students' longer study time indicated a positive impact of the exam which motivated the students to study harder (Mardapi \& Kartowajiran, 2009). It was argued that many students especially the low achievers and the deprived students made little efforts to study the subjects if there had been no high stake standardised national examination (Yulia, 2014). However, many students got exhausted physically and cognitively and felt frustrated (Mardapi \& Kartowajiran, 2009).

On the other hand, the extra study time the students had was found to have little to do with developing the students' English ability. What students learned inside the classrooms at school and at a tutoring institution was predominantly directed to preparing them for the exam (Mukminin et al., 2013; Sukyadi \& Mardiani, 2011; Suroyo, 2012; Yulia, 2014). In other words, the students were "learning to do the exam". Whereas, the exam was designed in a multiple-choice format. As a result, the students were drilled with samples of multiple-choice test items that were predicted to appear in the exam. That means, students were trained exam strategies, rather than acquiring and developing the knowledge and skills to be communicatively competent in the target language. This contradicts with the contemporary theory on language learning. Scholars have argued that the goal of a language learning is to help learners acquire and develop the knowledge and skills of listening, reading, speaking and writing in the target language that will allow them to competently operate in real life situations where the target language is used as the primary means of communication (Hughes, 2012; Weir, 2005). This goal seems unachievable if the learning is focused largely on answering multiple-choice exercises which heavily measure cognitive ability.

Apart from the students' study time, studies also showed that the exam had made English teachers to work harder. Mardapi and Kartowajiran (2009) reported that most of the teachers working in twenty different schools they surveyed felt more motivated to teach their students. They had a considerable pressure for making their students all pass the exam. In a different part of the country, a study done by Mukminin et al. (2013) in Jambi, confirmed that 12th grade (final year at senior high school level) teachers who taught English subject and other subjects tested in the national examination were considerably occupied with making sure that the final year students would succeed in the exam. However, the findings showed that teachers of non-exam subjects had considerably less work and pressure. The teaching hours for national examination subjects were doubled and extra classes after school hours were set up. Tryout tests and quizzes were administered to monitor the students' progress in meeting the cut-off score for passing the exam. This suggests how teaching was like inside the classroom. The English teachers tended to disregard the curriculum contents and the skills that were not tested in the exam, but were predominantly directed to teach strategies of how to best deal with the items of the exam in order to at least pass the required score (Mukminin et al., 2013; Sukyadi \& Mardiani, 2011; Yulia, 2014).

Having said that, the exam was found to be relatively controversial among teachers. Most of the teacher participants in Sleman regency, as studied by Mardapi and Kartowajiran (2009) through survey, had positive attitude towards the exam; they thought that it positively encouraged students to increase their study efforts. In contrast, all of the teacher participants in Jember regency, as investigated by Mukminin et al. (2013) through qualitative research, strongly expressed their discontent for the exam. They shared the same feelings and experiences. They narrated that the exam had forced them to ignore non-exam contents. They admitted that they were expected to do anything to help their students. They had to drill them to be able to succeed in the exam and even were asked to provide the answer key to the students. This was reported to be problematic. School's ability in helping students to pass the exam was argued to determine the school's status and the quality and quantity of the following enrolments. All this, as claimed, largely rested on the shoulders of the exam subject teachers. For this reason, the teachers reported that they were unable to help the students develop their English communicative competence through a range of classroom activities that develop necessary micro and macro skills of the target language.

At this stage, it is worth uncovering that the exam saved low competent teachers. They taught exam strategies to compensate their deficiency in delivering effective classroom instructions. Yulia (2014), who investigated twelve different schools which represented five hundred schools, on the 
English language teaching and curriculum in Yogyakarta province, discovered that most of the teachers were not competent in English language nor in English language teaching. Inside the classrooms, they primarily taught grammatical and vocabulary lessons which resonate the outdated English teaching methodology known as "grammatical translation" which has been widely criticised for its failure to allow foreign language learners to be communicatively competent in the language (Fulcher \& Davidson, 2007; Weir, 2005). Furthermore, the teachers had little idea of how to teach the micro and macro skills that construct a communicative competence and to design activities that would let students to acquire and develop these skills. They employed teacher-centered teaching and predominantly used Indonesian language. For this reason, teaching testing skills was favoured since it does not require much English proficiency and English teaching expertise. This then resulted in low English proficiency of many Indonesian graduates regardless the many years of their formal English instructions (Dardjowidjojo, 2000; Sukyadi \& Mardiani, 2011).

Nevertheless, what happened inside the classrooms as a result of the pressure of the exam was not without the principal's consent. Some teachers, the participants of the research done by Mukminin et al. (2013), reported that their school principals were so worried that they asked their English and other exam teachers to do anything they could to help the students pass the exam. They even asked them to secretly supply the exam answers to students. Such illegal assistance occurred in many places in the country and "exam leak" was a widespread phenomenon done not only by the school member but also other concerned parties e.g. tutoring institution etc. (Mukminin et al., 2013). Another strategy that principals did to help the students was by running extra classes after the school hours (Suroyo, 2012; Yulia, 2014). This strategy was reported to have been very common in the country. The sole reason for this was argued to prepare the students for the exam. This program was either done by the school independently by employing their own teachers, by hiring external people to teach, or by collaborating with a tutoring institution. It was found that this program was compulsory for the students to attend.

As a consequence, it was reported that the parents of the students were also impacted by the national examination. Clearly, they had to spend additional amount of tuition for the extra classes program for their children. Yulia (2014) found out that only those coming from very low socioeconomic background who did not send their children to attend extra classes program because they had nothing to pay. This shows that most parents were eager to send their children to attend extra classes program which made them have extra expenses. Moreover, some parents were even willing to pay double for sending their children to attend both program run by the school and the one run by an external tutoring institution. This happened because parents were worried that their children would not pass the exam and therefore could not graduate from their final year (Sukyadi \& Mardiani, 2011).
To many parents, failing an exam was a disaster; it was a waste of money, time and energy for a year their children had spent at school. Students who failed had to repeat another year or alternatively had to take a different type of high school certificate which was normally taken by drop-out students, which was regarded as socially undesirable for middle and high socioeconomic families (Yulia, 2014).

What the parents felt and thought about the exam and its consequence to a large extent represented how contemporary English language learning was perceived by the society. As reported earlier, within the educator workforce involving teachers and school leaders, exam strategies had become a common association of a "good" learning, in spite of its being a foreign language learning context, in the country. The high stake consequence was argued to have forced many educators to focus on drilling students to succeed in the exam. This resulted in the fact that added values, meaningful knowledge and useful skills were given much less attention in schools which was supposed to be a bridge for students to arrive in the real life in the society (Mukminin et al., 2013; Yulia, 2014). It could probably be argued that the exam had motivated students to study hard, parents to provide extra support and school to make additional preparations (Mardapi \& Kartowajiran, 2009), yet one could debate that in real life, it is unlikely that students would do "multiple-choice type" for real life tasks that involve a set of communicative competence i.e. grammatical, discourse, sociolinguistic and strategic competence (Canale \& Swain, 1980) cited in Yulia (2014)

In a larger scale, the high stake pressure of the exam was believed to have caused the explosion of tutoring programs across the archipelago. Parents are worried. They need to help their children prepare better to pass the exam. Demand for after-school-hour study programs increases. Tobing (2013) noted that according to the data by the Directorate of Course and Training in 2012, there were roughly 13.446 different tutoring institutions. Each of these institutions was reported to have up to a hundred branches across the country. It is worth pointing out that the number which represents a much bigger number of branches excludes the tutoring programs that each school runs independently and also excludes the unregistered tutoring institutions which could have outnumbered the number of the registered institutions. One could have highlighted that the exam had had a considerable impact on education business industry. Schools had started to get into a more business practice. Business people were found to make more profits. Parents had to spend more money. Students' life was full with school, homework, try-outs, after school lessons, and exam which left little space for them to enjoy their life according to the nature of their developmental stages. All this could imply that a misconception of what makes a good language learning was widespread in the society across the archipelago due to the high consequence of the exam. 


\section{CONCLUSION}

To sum up, this paper has tried to answer the research question of what impacts the English national examination has on the school community and on the society. Based on the discussion above, it could be concluded that the exam generated both educational and social consequences. Students' learning was reported to have been heavily directed to facing the exam which resulted in the marginalisation of other learning areas. Adding to this, teachers' teaching was reported to have been misleading as it ignored the importance of helping students develop communicative competence in the target language. The exam ironically saved low capacity teachers and did not encourage them to learn to improve their expertise. Principals preferred ways that would ensure the success of the students in passing the exam even if they had to conduct problematic policy. Furthermore, parents were discovered to have encountered additional financial consequences for wanting to see their children graduate from their final year. All this was believed to have generated a common misconception of how language classrooms had to operate which was simply to foster exam strategies. This resulted in the outburst of tutoring business industry in the country. In a broader scale, the exam is responsible for the formation and the spread of the malpractice in language learning classrooms in schools and in tutoring institutions. As an implication, these findings highlight the need to carry out a research that thoroughly investigates what factors influence the formation of the malpractice in language learning classrooms and their relation to the impacts of the English national examination in Indonesia.

\section{REFERENCES}

Bachman, L. F., \& Palmer, A. S. (1996). Designing Language Test. Oxford: Oxford University Press.

Dardjowidjojo, S. (2000). English Teaching in Indonesia. EA Journal, 18(1), 22-30

Fulcher, G., \& Davidson, F. (2007). Language, Testing, and Assessment. New York: Routledge.

Green, A. (2006). Watching for washback: observing the influence of the International English Language Testing System academic writing test in the classroom. Language Assessment Quarterly, 3(4), 333-368.

Harlen, W. (2005). Teachers' Summative Practices and Assessment for Learning -- Tensions and Synergies. The Curriculum Journal, 16(2), 207 - 223.

Herman, J. L. \& Golan, S. (1993). The effects of standardized testing on teaching and schools. Educational measurement: issues and practice, 12(4), 20-25.

Huda, N. (1999). Pengajaran Bahasa Inggris di Indonesia: Perkembangan dan Prospeknya. in P. Pannen, Zairulsyah, R. Sitompul, A. Tarore (Eds.), Cakrawala Pendidikan. Jakarta: UT.

Hughes, A. (2012). Testing for Language Teachers. Cambridge: Cambridge University Press.

Mardapi, D., \& Kartowagiran, B. (2009). Dampak ujian nasional. Laporan Hasil Penelitian Jurusan Penelitian dan Evaluasi Pendidikan. Yogyakarta: State University of Yogyakarta.

Mukminin, A., Haryanto, E., Makmur, Failasofah, Fajaryani, N., Thabran, Y., \& Hamzah, S. A. N. (2013). The achievement ideology and top-down standardized exam policy in Indonesia: voices from local English teachers. Turkish Online Journal on Qualitative Inquiry, 4(4), 19-38.

Sukyadi, D., \& Mardiani, R. (2011). The washback effect of the English national examination (ENE) on English teachers' classroom teaching and students' learning. K@ta, 13(1), 96-111.

Suroyo (2012). Penerapan bimbingan belajar untuk meningkatkan motivasi belajar menghadapi ujian nasional pada siswa SMK. Jurnal Manajemen Pendidikan, 7(2), $103-108$.

Tobing, R. L. (2013). Criticising the mushrooming of tutoring institutions in Indonesia. Unpublished paper, Master of Educational Management. Pekanbaru: State University of Riau.

Weir, C. (2005). Language Testing and Validation: An Evidence-based Approach. New York: Palgrave Macmillan.

Wiliam, D. \& Black, P. (1996). Meanings and consequences: a basis for distinguishing formative and summative functions of assessment? British Educational Research Journal, 22(5), 537-548.

Yulia, Y. (2014). An evaluation of English Language Teaching programs in Indonesian Junior High Schools in Yogyakarta province. Unpublished PhD thesis. Melbourne: RMIT University. 